\title{
Understanding Stoic and Epicurean ethical 'training' in light of the DPR model
}

\section{$\underline{\text { 1. Introduction }}$}

According to the French philosopher and intellectual historian Pierre Hadot, modern philosophy has somewhat lost its way. Where ancient philosophy 'proposed to mankind an art of living' he wrote, 'modern philosophy appears above all as the construction of a technical jargon reserved for specialists'. ${ }^{1}$ In recent years however, there has been renewed interest in the conception of philosophy as a way of life. A number of important book length studies, ${ }^{2}$ and a range of journal articles have focussed on the topic, and innovative projects such as Modern Stoicism ${ }^{3}$ have successfully engaged large numbers of people from around the world in practising philosophical techniques in their day-to-day lives.

Philosophy in the time of the Stoics and Epicureans was commonly conceived of as comprising three branches - namely physics, ethics and logic ${ }^{4}$ - and whilst one's philosophical worldview (and thus one's philosophical way of life) followed from the closely interconnected relationship between these three branches, it was primarily with practical ethics that the thinkers I will address here were concerned. ${ }^{5}$ In this practically oriented

\footnotetext{
${ }^{1}$ Hadot, 1995 p. 272

${ }^{2}$ As well as the work of Hadot $(1995 ; 2009)$ examples include the scholarly works of Nussbaum (1994), Long (2002) and Cooper (2012) as well as popular books of philosophy aimed at a more general readership such as Pigliucci (2017), Irvine (2009), Robertson (2013) and Evans (2012).

${ }^{3}$ https://modernstoicism.com/

${ }^{4}$ See Cooper (2012, pp.3-4) for discussion of the ways in which philosophy was divided in ancient Greece and Rome, and subsequently.

5 See for example Epicurus (LS 25C); 'Empty are the words of that philosopher who offers no therapy for human suffering' or Meditations (10.16) 'No more roundabout discussion of what makes a good man. Be one.'
} 
conception of philosophy, one's education appears as a form of training intended to help the aspiring philosopher towards the school in question's conception of the good life.

Philosophical texts and arguments were studied, skills in reasoning honed and unhelpful beliefs and opinions refuted, but a philosophical education was not to be confined to the classroom. One's learning was to be demonstrated in the extent to which one's character and life were informed and shaped by it, and theoretical learning for the sake of abstract understanding alone was of little or no value. ${ }^{6}$ As such, the student of ancient philosophy can usefully be considered in terms akin to professionals or craftsmen; those who seek not theoretical or abstract knowledge, but technical understanding and practical competence. ${ }^{7}$

With this in mind, I will argue in this article that modern research drawn primarily from the field of psychotherapy training can helpfully illuminate the processes involved in philosophical character development, such as was aimed at in ancient Greek and Roman practical ethics. Specifically, I will argue that the Declarative-Procedural-Reflective (DPR) model developed by James Bennett-Levy and colleagues ${ }^{8}$ as a conceptual framework for understanding the mechanisms through which therapists acquire and refine therapy skills, provides a useful lens through which to understand the philosophical training that sits at the heart of much ancient ethical philosophy. I argue that there are striking parallels between the processes and phases of learning as described by Bennett-Levy and colleagues with regards to therapists in training, and those of the student in practical ethics. As such, I suggest that

\footnotetext{
${ }^{6}$ See for example Epictetus Discourses 3.21.4-6

${ }^{7}$ Consider for example Epictetus Discourses 2.14.7. Similar themes are touched upon in Plato's Gorgias (e.g. 514e). For an interesting discussion of this in full, see Chapters $2 \& 3$ of Sellars (2009).

${ }^{8}$ Bennett-Levy, 2006; Bennett-Levy \& Thwaites, 2007
} 
this empirically grounded, cognitive model of therapist skill development can usefully explain and conceptualise the processes involved in training for the philosophical way of life.

As noted above, despite the general trend in modern philosophy towards specialisation and academic study, the idea that philosophy (especially philosophy from the Stoic tradition) can serve a practical, therapeutic or useful function for modern readers has again become prominent in some quarters of philosophy. ${ }^{9}$ If indeed it is true that applied philosophy can shape our lives and behaviours in ways experienced by many as fulfilling and helpful, then a conceptual framework that describes the mechanisms involved in effective applied philosophical training stands to be of significant value to contemporary students and teachers of the subject.

\footnotetext{
${ }^{9}$ The appearance of popular books of practical or lived philosophy such as Evans (2012), Irvine (2009), Robertson (2013) and Pigliucci (2017) attests to this fact. Interestingly, the existing evidence from Stoic Week in recent years has also begun to collect an emerging empirical support for the idea (e.g. LeBon, 2018). The question regarding whether ancient philosophy can be properly therapeutic has been addressed by a number of thinkers expressing a range of views in the last couple of decades. See for example Nussbaum (1994); Williams (1994); Sorabji (1997) and Gill (1985). The question has also been picked up again recently by John Sellars in an article entitled What is philosophy as a way of life? Here Sellars offers an interesting consideration of the conflict between considering philosophy as 'therapeutic' and philosophy as being something intent on helping us understand the world as it truly is. As Sellars notes, whilst all good philosophy takes a serious interest in the idea of philosophy as a way of life, it cannot simply be a 'project aimed at making us feel good, because truths can sometimes be uncomfortable' (Sellars, 2017 p.49). With this in mind, we might conclude that whilst practically focussed philosophy may remain a useful and important tool in the pursuit of a meaningful life, it cannot - whilst truly remaining philosophy - be reduced solely to something intended to rid us of negative feelings.
} 


\section{The Declarative-Procedural-Reflective (DPR) Model}

Across the last couple of decades there has been increased interest in the processes through which trainee therapists acquire, develop, maintain and refine therapy skills. ${ }^{10}$ The DPR model was developed to offer a theoretical framework for understanding these processes from an information processing perspective. ${ }^{11}$ In order to develop my argument for how this model may help us make sense of the educational approach underpinning training in practical ethics, it will be useful to begin by briefly outlining the central features of the DPR model. ${ }^{12}$

\subsection{The three systems of the DPR model}

The DPR model identifies three systems - the declarative, procedural and reflective systems - that provide a conceptual framework for understanding the way that therapists learn therapy skills, from an information-processing perspective. ${ }^{13}$

The declarative system is concerned with 'knowing that' ${ }^{14}$ and is the store-house of propositional knowledge that we may speak, read or talk about. ${ }^{15}$ In cognitive therapists for instance this would include factual knowledge about the cognitive model of panic disorder for example. Declarative knowledge is often acquired through didactic teaching, observation of others or reading, and is frequently a focus during the early stages of therapist training. ${ }^{16}$

\footnotetext{
${ }^{10}$ Binder, 1993; Skovholt, 2001

${ }^{11}$ Bennett-Levy, 2006; Bennett-Levy \& Thwaites, 2007

${ }^{12}$ For detailed descriptions of the DPR model, see Bennett-Levy, (2006) and Bennett-Levy \& Thwaites, (2007).

${ }^{13}$ Bennett-Levy, 2006; Bennett-Levy \& Thwaites, 2007

${ }^{14}$ Bennett-Levy, 2006 p.59

${ }^{15}$ Bennett-Levy \& Thwaites, 2007 p.256

${ }^{16}$ Bennett-Levy, 2006 p.59
} 
This factual knowledge establishes the foundations upon which practical know-how can be built and is a necessary pre-requisite for the newcomer before advancing to skilled practice. Before trainees can practice using a cognitive-therapy approach to treating depression for example, it is necessary that they first understand the steps of the intervention and the rationale for using it.

However, declarative knowledge alone is clearly insufficient for producing skilled therapists. Without the opportunity to apply such learning practically, and without encouraging the learner to be active in the learning process or to consider it in relation to the situations in which such knowledge may be used, there is a risk of producing what cognitive psychologists have called 'inert' knowledge. ${ }^{17}$ 'Inert' knowledge describes information understood on an abstract or theoretical level, but inaccessible or unhelpful to the learner in situations in which this may be of use. Such 'inert' knowledge will not result in the changes in thinking, perceiving or behaving that training in therapy (or philosophy as a way of life) is aiming at. If the declarative system then is concerned with 'knowing that', the procedural system is concerned with 'knowing how' and 'knowing when' to use such knowledge. ${ }^{18}$ Procedural knowledge is often stored implicitly, with more experienced practitioners reporting that they 'just know' how to manage a particular situation or what to do in a given scenario. The procedural system is constantly updated as practitioners advance in their practice, and it is comprised of increasingly refined sets of rules, plans and procedures that allow more experienced therapists to make decisions about how to respond in any therapeutic situation. In part, procedural knowledge develops through experience; through putting learning into practice, through trying things out and through considering knowledge in relation to the

\footnotetext{
${ }^{17}$ Binder, 1993 p.312

${ }^{18}$ Bennett-Levy, 2006 p.59
} 
context in which it applies. As remarked by Boud and colleagues however, 'experience alone is not the key to learning ${ }^{19}$ and development requires not simply having an experience but learning from it. According to the DPR model, subsequent development - and especially that which advances the more experienced therapist towards expertise - relies on the third component of the model, reflection.

Unlike the declarative and procedural systems, the reflective system does not permanently store information. The reflective system instead plays a comparative role, importing knowledge from the declarative and procedural systems and enabling new learning to be uncovered through the way this knowledge is reconceptualised or compared to other learning or experience. ${ }^{20}$ The reflective system enables learners to mentally represent to themselves past experiences and prior learning, and examine their thoughts, feelings and existing knowledge in ways that can lead to new understandings. In this way, reflection is seen as the 'engine driver' for therapist development. ${ }^{21}$

According to the DPR model then, whilst didactic teaching and procedural practice will be the mainstays of the learning experience for the relative newcomer, it is through reflection that therapists continue to develop towards expertise. ${ }^{22}$

\section{Ancient philosophy, practical ethics and the DPR model}

That ancient philosophy was supposed to inform an entire way of life (and not be a subject confined to the classroom or intent simply on developing abstract, declarative knowledge), is

\footnotetext{
${ }^{19}$ Boud et al., 1985a p.7

${ }^{20}$ Bennett-Levy, 2006; Bennett-Levy \& Thwaites, 2007

${ }^{21}$ Bennett-Levy et al., 2009 p.119

${ }^{22}$ Ibid.
} 
apparent in many of the writings we have from this period. ${ }^{23}$ Despite this, contemporary scholars have not unanimously agreed on the precise form and nature of ancient philosophy. For writers such as Pierre Hadot, philosophy in Greece and Rome was 'a mode of existing-inthe-world, which had to be practiced at each instant, and the goal of which was to transform the whole of the individual's life'. ${ }^{24}$ It was a 'determinate lifestyle', which engaged 'the whole of existence ${ }^{25}$ and was as such practical in its very essence and nature. For others such as John Cooper however, the practical application of philosophy is but one component of the subject, and ancient philosophy itself was rather 'the art or discipline that develops and perfects the human capacity for reason, ${ }^{, 6}$ with a 'certain, specifically and recognisably philosophical, style of logical, reasoned arguments and analysis' at its core. ${ }^{27}$

Despite these disagreements, commentators and ancient sources have generally agreed that in the pursuit of wisdom, intellectual or theoretical understanding alone serves little purpose. As such, despite its grounding in declarative knowledge and understanding, training in practical ethics in the Stoic and Epicurean schools was a fundamentally practical and characterforming undertaking. It is precisely in relation to this aspect of the Stoic and Epicurean philosophical projects that I suggest the DPR model provides a useful and enlightening framework.

\footnotetext{
${ }^{23}$ Whilst my focus in this article is primarily on the Stoics and Epicureans, this emphasis on the practical, lived nature of philosophy was by no means confined to them. See for example Socrates in the Apology (38a) or what is said of Diogenes the Cynic (Lives of The Eminent Philosophers, VI.22).

${ }^{24}$ Hadot, 1995, p.265

${ }^{25}$ Ibid, p.83

${ }^{26}$ Cooper, 2012, p.6

${ }^{27}$ Ibid, p. 17
} 


\subsection{Foundational knowledge}

So how did a philosophical education function for those seeking the philosophical way of life in the Hellenistic and Roman periods? As we have seen, the Roman Stoics and Epicureans were especially interested in how philosophy could help us to live happier and more flourishing lives, but these ethical positions were intimately connected to the school's wider philosophical worldviews. Consequently, students attending the lectures of Epictetus for example would have been encouraged by their teacher to see their learning in terms of training for what A.A. Long refers to as the 'human profession'. ${ }^{28}$ Training in the 'human profession' - much like training in a medical, musical or any other profession for that matter - begins with the acquisition of relevant declarative knowledge to provide the foundation to inform one's practice. Just as therapists in training may begin by learning the fundamentals of a cognitive-behavioural approach to therapy, philosophers in training will begin by studying the world around them, the nature of human beings, and the writings of the philosophers who have preceded them. ${ }^{29}$

Before students could hope to practice and to live as a Stoic or an Epicurean for example, it was first necessary to comprehend some of the principles that underpinned these

\footnotetext{
${ }^{28}$ Long, 2002, p.225

${ }^{29}$ In his Pursuits of Wisdom John Cooper explicitly rejects the idea that the philosophical way of life could follow genuinely from a simple acceptance and uptake of established philosophical ideas about how to live (Cooper, 2012 p.18). He argues instead that such a life can only result from the use of reason to establish what is true about the world and how we ought to live. It is worth commenting here that the link between declarative and procedural knowledge remains whether one sides with Cooper on this point, or with Hadot, who remarks for example that 'every person who lived according to the precepts of Chrysippus or Epicurus was every bit as much a philosopher as they' (Hadot, 1995, p.272).
} 
philosophies. ${ }^{30}$ As noted in an article on Epicurean ethics by Michael Erler and Malcolm Schofield, Epicurus maintained that benefiting in one's daily life from living as an Epicurean began with 'knowledge and acceptance' of the basic teachings underpinning his philosophy. ${ }^{31}$ For the student of Stoicism too, one's training must begin with the amassing of some declarative knowledge about the nature of the world and human beings as seen according to reason. ${ }^{32}$ Consequently, students of Stoic philosophy in the Roman period for example would expect to study philosophical texts and understand the theories informing the way of life advocated by their particular school. ${ }^{33}$

Much of this initial learning then concerns the declarative system of Bennett-Levy's DPR model; 'knowing that' the universe is rationally governed in the case of the Stoics for example ${ }^{34}$ or 'knowing that' there are both natural and unnatural desires in the case of the Epicureans. ${ }^{35}$ But such declarative knowledge alone will not suffice to shape or form the student in the manner that either Epicurus or Epictetus were aiming at, and it seems that these

\footnotetext{
${ }^{30}$ In her Therapy of Desire Martha Nussbaum highlights the ways in which the attitudes towards genuine scientific enquiry differed amongst the schools of Greece and Rome. In the opinion of Nussbaum, the Epicureans were notable for their 'unscientific' approach. Rather than being interested in genuine scientific discovery she argues, Epicurus built his system around his ideas such that his philosophical theory would support the positions he started out from (Nussbaum, 1994, p.123-4). It is perhaps useful to highlight again that this does nothing to detract from the position I am developing here. Regardless of the extent to which Epicurean principles were scientifically grounded, one's philosophical training required learning and accepting the principles which supported the system.

${ }^{31}$ Erler \& Schofield, 1999, p.644

${ }^{32}$ See for e.g Discourses 2.14.10-13

${ }^{33}$ Gill, 2014; Raydams-Schils, 2010

${ }^{34}$ Epictetus Discourses 2.14.11

${ }^{35}$ Epicurus Letter to Menoeceus. 128
} 
ancient philosophical teachers too were aware of the possibility of generating 'inert' knowledge. In an illuminating article on philosophy and education in Roman Stoicism, Gretchen Reydams-Schils remarks that whenever Epictetus mentions such didactic learning in the Discourses 'he more often than not sounds a cautionary note, claiming that it does one no good whatsoever to be able to interpret and understand Chrysippus' works... unless one can also put those insights into practice and show how one has changed for the better as a result of one's reading' ${ }^{36}$ The point here for Epictetus - and indeed for many other philosophers in ancient Greece and Rome ${ }^{37}$ - was that abstract understanding or 'inert' knowledge were not the goal of philosophical learning. We come to philosophy, they remind us, not simply so that we may be able to recite texts or learn theories, but so that we can be genuinely shaped and informed by such learning. Hence, Epictetus remarks how philosophers should not therefore 'be contented merely to learn, but should add practise too and then training, 38

\subsection{The practical application of philosophical ideas}

So how was the student of ancient applied philosophy to go beyond the purely academic arena of declarative knowledge? How was she to transfer this into what she did, into the procedural knowledge of how to live in accordance with such learning?

\footnotetext{
${ }^{36}$ Reydams-Schils, 2010 p.566. Sharpe (2014) also develops this idea in depth.

${ }^{37}$ Consider for example the warning of Polemo reported in Diogenes Laertius' Lives of The Eminent

Philosophers, that without practice and action we run the risk of becoming like a man who knows a text book by heart or who can ask questions with great skill, but has never practised any of these ideas and lives at variance with himself in the ordering of his life (Lives. IV 18).

${ }^{38}$ Epictetus Discourses 2.9
} 
According to the DPR model, the trainee therapist equipped with some foundational knowledge requires the opportunity to practice applying such ideas and to observe others already skilled in doing so. Bennett-Levy talks here about activities such as role-play, shadowing peers, practising clinically and using supervision as effective methods in helping students develop and improve their procedural skills. ${ }^{39}$ A number of texts from ancient authors demonstrate that a range of similar techniques appear to have been advocated for or utilised by the aspiring student of practical philosophy. In the Meditations of Marcus Aurelius for example, the Stoic Emperor recounts the traits and behaviours he has admired in the character of those around him. Just as the trainee therapist who shadows more experienced colleagues and learns from the way they see therapeutic encounters being managed and handled, Marcus reminds himself of how he has learned from seeing those around him live in accordance with the values he admires. ${ }^{40}$

In his Letter to Menoeceus, Epicurus advises his friend to exercise himself 'in these and kindred precepts day and night, both by yourself and with one who is like-minded' ${ }^{41}$ This recommendation to 'exercise' oneself in the ideas contained within the letter demonstrates the importance Epicurus attached to absorbing ideas fully and applying them practically to one's life. 'Exercising' oneself in the ideas of Epicurean philosophy meant practising the ideas and using them to shape and inform one's general way of living. Behavioural changes such as 'habituating oneself to inexpensive diet' ${ }^{42}$ or more meditative exercises such as 'accustoming

\footnotetext{
${ }^{39}$ Bennett-Levy, 2006 p.69

${ }^{40}$ See for e.g. Meditations 1.3 'From my mother: piety, generosity, the avoidance of wrong-doing and even the thought of it; also, simplicity of living, well clear of the habits of the rich'.

${ }^{41}$ Epicurus Letter to Menoeceus 135

${ }^{42}$ Ibid 131
} 
oneself' to the idea that death is nothing to us through deliberate meditation on the idea ${ }^{43}$ would each have played a part in bringing these ideas to life. It seems that Epicurus himself was known to 'practice what he preached" ${ }^{44}$ and the modest, communal life he lead in The Garden was considered by many as an example to be followed. ${ }^{45}$ Like the trainee therapist then, the 'trainee' Epicurean sought to develop through applying ideas in practice and learning from the example of those already skilled in doing so.

In developing his account of the Stoic 'art of life', John Sellars describes what he refers to as the 'technical conception of philosophy' in which 'the study of philosophical arguments, theories and doctrines is merely the first part of a philosophical education' ${ }^{46}$ Sellars traces this conception of an art of living back through Socrates and mounts a compelling case for how and why philosophy for the Stoics should be understood in terms analogous to those of certain arts and crafts. On such terms, philosophical theories and doctrines are first mastered before a subsequent "period of practical training in which the apprentice will attempt to digest this material in order to produce the actions or product appropriate to their art' ${ }^{47}$ So, just as the DPR model describes the importance in therapist training of developing procedural knowledge and skills through the practical application of one's learning, the Stoics too it

\footnotetext{
${ }^{43}$ Ibid 124

${ }^{44}$ Long, 1974, p.72

${ }^{45}$ Bergsma, Poot \& Liefbroer, 2008, p.399

${ }^{46}$ Sellars 2007, p.170

${ }^{47}$ Ibid. 170
} 
seems acknowledged the need to begin by setting a foundational knowledge base, before moving into the realm of practical and procedural training. ${ }^{48}$

\subsection{Spiritual exercises}

Contemporary understanding regarding the manner in which philosophy was practised in ancient times owes much to the influential work of Pierre Hadot and his notion of spiritual exercises. ${ }^{49}$ Hadot was in fact careful to clarify that the 'spiritual exercises' he finds at the heart of ancient philosophy are not simply practice that is added to abstract philosophical theory ${ }^{50}$ but his writings on the nature of ancient philosophy are significant for illuminating the manner in which elements of philosophy were practised, acted out and lived by. Throughout his work, Hadot describes a number of distinct spiritual exercises that he suggests were practised by philosophers throughout antiquity as a means of forming themselves in line with their philosophy. ${ }^{51}$ These exercises, which he describes as 'voluntary, personal practices meant to bring about a transformation of the individual', ${ }^{52}$ characterise

\footnotetext{
${ }^{48}$ See for e.g. Discourses 1.26 .3

${ }^{49}$ Hadot, 1995; Hadot, 2009

${ }^{50}$ For Hadot, all of ancient philosophy itself is an exercise (Hadot, 2009 p.88). As such, and as noted in a 2013 article by Gwenaëlle Aubry, theory and practice are for Hadot two essential and inextricably linked aspects to ancient philosophy (Aubry, 2013).

${ }^{51}$ Hadot also includes two lists of spiritual exercises attributed to Philo of Alexandria (Hadot, 1995 p.84)

52 (Hadot, 2009 p. 87). As is hinted at in this description, spiritual exercises in Hadot's conception cover a broad range of activities. Indeed, for some authors, Hadot's conception of spiritual exercises is so general as to become virtually meaningless (e.g. Narcy, 2000)
} 
ancient philosophy as a way of life for $\operatorname{Hadot}^{53}$ and are a key feature for understanding how one developed procedural knowledge and competence in the philosophical way of life. ${ }^{54}$

One avoids the fate of 'inert' declarative knowledge then through training oneself in these ideas and applying them practically to one's life. In practising these ideas one might, as we have seen above, engage in meditation on topics such as death, ${ }^{55}$ the possibility of losing what we currently have ${ }^{56}$ or our place in the world when seen from a cosmic perspective. ${ }^{57}$ One might make a point, as Marcus Aurelius appears to have done, of reminding oneself about the true nature of things before him, so as not to be carried away by impressions. ${ }^{58}$

\footnotetext{
${ }^{53}$ Hadot 2009, p.88

${ }^{54}$ The centrality of 'spiritual exercises' to ancient philosophy has not however been universally or uncritically accepted in the scholarly literature. In his Pursuits of Wisdom for example, John Cooper argues that the suggestion that spiritual exercises play as central a role as Hadot claims in ancient philosophy undermines the rational foundations of the philosophical life. There Cooper suggests that 'Those nonrational practices that
} Hadot describes as "spiritual exercises"... had, and could have, at most a secondary and very derivative function in the philosophical life during the heyday of ancient philosophy' (Cooper, 2012 p.22). Similarly, in The Therapy of Desire Martha Nussbaum complains that the emphasis on such formative techniques found in Hadot and others' interpretation 'obscures... the dignity of reason' (Nussbaum, 1994. p.353). For a thoughtful and effective defence of Hadot against the criticism that his emphasis on spiritual exercises undermines philosophy's rational and theoretical elements, see for example Sharpe (2016) or del Nido (2018).

55 'Accustom thyself to believe that death is nothing to us' (Epicurus Letter to Menoeceus. 124)

56 'For by looking ahead to all that may happen as though it were going to happen, he will soften the attack of all ills' (Seneca On The Tranquillity of Mind. 11)

57 'when your talk is about mankind, view earthly things as if looking down on them from some high point above - flocks, armies, farms, weddings, divorces, births, deaths... all the medley of the world and the ordered conjunction of opposites' (Marcus Aurelius Meditations 7.48)

58 'How good it is, when you have roast meat or suchlike foods before you, to impress on your mind that this is the dead body of a fish, this is the dead body of a bird or pig' (Marcus Aurelius Meditations 6.13). 
Equally, one might undertake exercises in endurance or physical restraint such as taking cold water into one's mouth when thirsty and spitting it out, ${ }^{59}$ or deliberately doing away with luxuries for a period of time so as to train ourselves in not becoming reliant upon them. ${ }^{60}$ Other exercises take on a more overtly reflective or contemplative style such as bringing each day to a close with a reflection on how one has behaved, ${ }^{61}$ or commencing each morning with a consideration of the challenges one might meet in the day ahead. ${ }^{62}$ The precise nature of the exercises that one might engage in would then vary according to one's philosophical allegiances. But practical engagement with philosophical ideas in order that they might shape and inform one's character appears to have been central to both the Stoic and Epicurean conception of applied philosophy.

Through the living out and practising of such ideas, the student in ancient practical ethics would consistently update and expand both their declarative and procedural knowledge bases. One's declarative knowledge of the idea that 'death is nothing to us' for example is enhanced, refined and clarified through deliberate meditation on the topic. So too is one's understanding regarding how easy it is to go without life's little luxuries when one lives for a while without them. More importantly, through this repeated practice of key ideas one begins to develop

\footnotetext{
59 'If at any time you want to train yourself to endure hardship, do it for your own sake and not for others... if you ever find yourself extremely thirsty, take some cold water into your mouth and then spit it out again without telling a soul' (Epictetus Handbook, 47).

60 'Appoint certain days on which to give up everything and make yourself at home with next to nothing' (Seneca Letter 18); Similarly, Epicurus remarks how 'the habit of simple and inexpensive diet maximises health... also strengthens our character when we encounter luxuries from time to time' (Epicurus Letter to Menoeceus. 131)

61 'I examine the whole of my day, I retrace my actions and words...' (Seneca On Anger 3.36)

62 'Say to yourself first thing in the morning, today I shall meet people who are meddling, ungrateful, aggressive...' (Marcus Aurelius Meditations 2.1)
} 
procedural knowledge, of how and when to use ones philosophical principles effectively. ${ }^{63}$ In this way, the philosophical apprentice - much like the trainee therapist - becomes increasingly adept at understanding not only the principles underlying her art, but also the moments and manner in which to apply them. Such understanding may be the difference between 'knowing' in the abstract that luxurious foods do nothing to increase one's happiness, and understanding how to actually live well according to that knowledge.

\subsection{Developing expertise}

So far then we have considered two aspects to one's philosophical development; theoretical learning and practical training, ${ }^{64}$ and noted the correlation between these aspects and the declarative and procedural components of Bennett-Levy's DPR model.

In the Gorgias, Socrates had implied that expertise in any given art would be founded on a rational understanding of the relevant principles, but follow only from an extended period of practice based on such learning. ${ }^{65}$ Building on this, John Sellars suggests that in any given art - including the Stoic 'art of life' - it is training 'that transforms the apprentice into an expert whose mastery of the art in question is displayed in his or her actions', ${ }^{66}$

\footnotetext{
${ }^{63}$ Though in fact, as I shall argue below, such knowledge does not develop in an ongoing manner as a result of practice alone.

${ }^{64}$ As remarked by Sellars (2009, p.49) a number of ancient texts often cite these two elements as key, with the occasional inclusion also of natural ability.

65 (Plato Gorgias, 514e). Similarly, in Letters 94 and 95 Seneca concludes that despite the primary importance of doctrines in the philosophical way of life, both doctrines and precepts are typically required in order to achieve wisdom or the sort of character transformation that philosophy aims at.

${ }^{66}$ Sellars 2007, p.121
} 
But is it in fact the case that training and practice alone lead to mastery and expertise? In the context of therapist skill development, the DPR model describes that whilst 'didactic learning, modelling, practise and feedback form the key learning mechanisms for the relative newcomer, the principal strategy that takes a therapist from being average to expert is reflection'. ${ }^{67}$ It seems clear that the ancients too recognised the educational value of deliberate reflection on one's practice and as we have seen, a number of reflective exercises appear to have played an important role in the philosophical application of key ideas for both the Stoics and Epicureans. By using the DPR model as a conceptual framework for understanding their programme of ethical training, the significant role that such reflection plays in the formation of the philosopher-in-training is made clear.

\section{Ancient practical ethics and contemporary psychotherapy training}

In this article I have sought to draw attention to the points of contact between the processes involved in training in ancient practical ethics and contemporary psychotherapy. The close parallels between aspects of contemporary psychotherapeutic approaches (especially CBT and third-wave CBT approaches such as ACT) and ancient philosophical 'therapy' (notably that from the Stoic tradition) have been identified and discussed by a range of authors. ${ }^{68}$ These commonalities strengthen the parallels I am drawing here by highlighting some of the ways in which these two areas share some broader points of contact.

\footnotetext{
${ }^{67}$ Bennett-Levy, 2006 p.60

${ }^{68}$ Epictetus' remark that is in regards to the judgements men make regarding things, rather than the things themselves (Handbook 5) provides the corner-stone of modern cognitive therapy approaches. Cognitive Therapy's indebtedness to certain Stoic ideas is acknowledged directly by its founding figure (Beck, 1976). For an enlightening and extensive discussion of this parallel see Robertson (2010).
} 
Indeed, that a model which describes the processes involved in therapist skill development would also so helpfully describe the processes of training in practical ethics ought not surprise us. Evidently, the goal of these forms of training are not identical; one seeks the development of clinical competence, whilst the other a transformation of the entire way of being of the individual. In certain respects however, both are working in similar domains. In both contemporary therapist training and ancient practical ethics there is an interest with our inner and emotional lives; in understanding the ways in which emotion, cognition, desire, behaviour and so forth can interfere with or play a part in a full and flourishing human life. ${ }^{69}$ In discussing the development of the DPR model, Bennett-Levy draws attention to key features of the model that highlight why it applies so specifically to the process of therapeutic skill acquisition. Consideration of these factors also sheds light on the model's relevance for training in practical ethics. Bennett-Levy describes how he built on the pioneering work of Binder who had argued that therapeutic skill was best developed not solely through declarative learning, but through an emphasis on procedural practice. ${ }^{70}$ In an effort to more closely align such thinking with the wider adult learning literature - in which reflection plays such a key role ${ }^{71}$ - Bennett-Levy and colleagues embedded the notion of reflection into their model. Further, they comment how the incorporation of reflection was required to account for

\footnotetext{
${ }^{69}$ Significantly of course, contemporary therapist training and ancient practical ethics differ in the sense that therapists are training to be professional therapists, skilled in supporting others to manage emotional and psychological difficulties, whereas the student in ancient practical ethics is above all concerned with how these therapeutic ideas can be applied to herself. Whilst this difference is important, I suggest it does nothing to detract from the parallel I am drawing here.

${ }^{70}$ Bennett-Levy et al., 2009 ; Binder, 1993

${ }^{71}$ Boud et al., 1985
} 
the meta-cognitive demands placed on the therapist. ${ }^{72}$ Working well clinically requires an ability to identify, reflect on and think about one's own thought processes as well as those of one's clients. It requires an understanding of the way that one's own thoughts and emotions influence one's behaviour and the extent to which one can influence and control this.

Similarly, ancient practical ethics - often referred to as 'therapy' by the ancients ${ }^{73}$ - sought to understand, make sense of, and in some way exert influence over our emotional lives. 'Metacognitive demands' are placed on the practising Stoic for example, who examines her thinking about fame or posterity or suspends judgement before assenting to an impression. ${ }^{74}$ As such, just as with the developing therapist, mere declarative learning and practice alone are not sufficient. To learn from one's experience and to develop in one's efforts to live in a particular way, one must use reflection to reconsider one's experience, to understand how and why one acted as one did, and how one can develop in one's efforts to live in accordance with these ideas in the future. Consequently, here too, reflection is a critical concept. What made me act the way I did earlier? What went through my mind to make me lose my temper or give way to desire? Just like the developing therapist then, the reflective Stoic uses reflection to constantly update and refine her procedural knowledge base and to arrive at an ever more refined set of when-then rules, plans and procedures. ${ }^{75}$

\footnotetext{
72 Bennett-Levy et al., 2009, p.2

73 'For just as there is no use in medical expertise if it does not give therapy for bodily diseases, so too there is no use in philosophy if it does not expel the suffering of the soul' (LS 25C)

74 e.g. Meditations 10.31 and 8.13

${ }^{75}$ Just as the cognitive therapist may come to learn 'when a patient has clinical depression and withdraws, then assess level and kind of activity as well as achievement and pleasure' (Bennett-Levy, 2006, p.59), the practising Epicurean may say, 'when faced with temptation, then ask myself, what will happen if I satisfy this desire, and what will happen if I don't?' (see Vatican Sayings 71).
} 


\section{$\underline{5 . T h e ~ p l a c e ~ o f ~ r e f l e c t i o n ~ i n ~ a n c i e n t ~ p h i l o s o p h y ~}$}

The process of reflecting, alone or with others, is at the heart of the philosophical approach practised by many of the thinkers considered here and it is clear that such reflection carries with it far reaching philosophical potential. When Socrates engages his interlocutor in the various discussions we find in the Platonic dialogues, what we encounter is a sustained process of reflection and enquiry which can - and often does - lead to a radical overhauling of the initial conception regarding the idea. ${ }^{76}$ For the Stoics and Epicureans too, philosophical reflection plays a key role in challenging, developing and refining particular aspects of their philosophical stance. ${ }^{77}$ In this way, reflection in its broadest sense can be seen to play a more far reaching and potentially radical role in ancient philosophy than it does in the DPR model of therapist skill development.

In the DPR model, reflection focuses largely on one's use of the techniques and interactions learned and practised in one's clinical work. As such, whilst reflection here appears above all as a process geared towards refining one's understanding of - and competence in - particular elements of one's clinical work, reflection in ancient philosophy appears as something more fundamental. That deliberate, focussed reflection on our practice - of a kind similar to that envisaged in the DPR model of therapist skill acquisition - also played a significant role in ancient philosophical training however, is apparent from a number of the texts and thinkers we have considered already in this article. In a well-known passage from On Anger for

\footnotetext{
${ }^{76}$ Consider Socrates' well-known description in the Apology (38a) of how 'talking and examining both myself and others is really the very best thing that a man can do'.

${ }^{77}$ Consider for example Marcus Aurelius' frequent reflections on the possible ethical implications that follow from either the Stoic or Epicurean world-view; 'providence or atoms' (e.g Meditations 9.28).
} 
example, Seneca describes his nightly practice of self-reflection; 'I examine the whole of my day, I retrace my actions and words; I hide nothing from myself, pass over nothing' ${ }^{78}$ The formative value of such activity is clear. Through the examination of his thoughts and actions, Seneca provides himself the opportunity to consider where he has succeeded or fallen short in living in accordance with his values and his training. Describing the value of such reflective activity, Bennett-Levy writes that 'the significant point about self-reflection is that, through the autonoetic capacity to mentally represent past events, humans are able to engage in new learning often at a significant temporal distance from the occurrence of the event itself ${ }^{79}$ Importantly then, this learning is derived not simply from the experience itself - the 'bad habit' he had succeeded in putting right that day perhaps, or the discussion in which he spoke 'too aggressively' ${ }^{\prime}$ - 'but from a set of complex cognitive operations consciously carried out on the mental representation of the event in order to facilitate new understandings ${ }^{81}$ Such reflective activity was central to Stoic and Epicurean practice and has been described in light of modern research as amongst the most significant processes through which we can learn from our experience. ${ }^{82}$

For Bennett-Levy, reflection is a process defined by 'persistent self-questioning (or Socratic questioning from an external source)' ${ }^{83}$ Through these processes, we are able to re-evaluate our prior learning or experiences in ways that lead to new understanding, and the philosophers of ancient Greece and Rome were well attuned to this fact. 'Persistent self-

\footnotetext{
${ }^{78}$ Seneca On Anger 3.36

${ }^{79}$ Bennett-Levy, 2006 p.68

${ }^{80}$ Seneca On Anger, 3.36

${ }^{81}$ Bennett-Levy, 2006 p.68

${ }^{82}$ Staudinger, 1999

${ }^{83}$ Bennett-Levy, 2006 p.67
} 
questioning' dominates the reflective tone that Marcus Aurelius adopts in the Meditations for example, and it is frequently such 'Socratic questioning from an external source' that Epictetus subjects his listeners to in the Discourses.

In Seneca's nightly examination then, ${ }^{84}$ Marcus Aurelius' efforts to remind himself of what he has so far had the strength to endure, ${ }^{85}$ or the Epicurean practice of confession, ${ }^{86}$ we encounter the deliberate, after-the-fact examination of one's behaviour and thinking that Donald Schön identifies as central to professional development and describes as 'reflectionon-action' ${ }^{87}$ In light of the framework provided by the DPR model, the presence and importance of such activities takes on new significance. The model helps to explain the way in which more advanced philosophical students can use such reflection to further embed their learning and refine their understanding of how to apply it practically in their daily living.

According to the DPR model, the reflective system enables us to identify gaps in declarative knowledge or procedural skills by examining ourselves and our actions, and by comparing existing knowledge with new experiences. ${ }^{88}$ Through this process we become better able to discern the situations and ways in which to effectively use the techniques and ideas learned throughout our training, and we develop increasingly refined sets of rules and understandings regarding how to apply knowledge and respond to the activities and situations we face. ${ }^{89}$ In

\footnotetext{
${ }^{84}$ Seneca On Anger 3.36

${ }^{85}$ Marcus Aurelius Meditations 5.31 Nussbaum (1994, p.133-135).

${ }^{87}$ Schön, 1983

${ }^{88}$ Bennett-Levy et al., 2009

${ }^{89}$ Bennett-Levy, 2006 p.60
}

${ }^{86}$ See Philodemus' assertion that Epicureans 'should become accusers of ourselves, if we err in any respect' (On Frank Criticism, 51) cited in Nussbaum (1994). For a discussion of the Epicurean practice of confession see 
the context of philosophy as a way of life, this means reflecting on one's philosophical practice and coming to ever-clearer understandings of the manner in which one can effectively use the ideas and techniques from one's training. If I have found myself worrying about the possibility of illness or death, how does this compare with my understanding regarding the nature of sensation and the fact that death, as the privation of sensation, is nothing to be feared $?^{90}$ If I gave in to temptation in satisfying unnecessary desires then how could I approach similar situations in the future with greater resolve? What techniques from my Stoic or Epicurean training might I use to help me hold strong to my convictions in the future and how would they best be implemented?

Considering the literature on the value of reflection in therapist training, Bennett-Levy concludes that research leads 'to the logical conclusion that the capacity to reflect is arguably the central skill that trainers should be developing in trainees for ongoing professional development'. ${ }^{91}$ So given the parallels we have drawn here, what might be the implications of this for the contemporary study of philosophy as a way of life, and how can the formative and educational value of reflection on our practice be harboured?

\section{Implications for the contemporary practice of 'philosophy as a way of life'}

In this article I have offered a reading of ancient ethical training - notably Epicurean and Stoic - through the lens of the DPR model of Bennett-Levy and colleagues. I have argued that the DPR model provides an enlightening framework - one grounded in contemporary

\footnotetext{
${ }^{90}$ Epicurus Letter to Menoeceus. 124

${ }^{91}$ Bennett-Levy, 2006 p.61
} 
psychological and educational research - for understanding the mechanisms and systems involved in effective character development and ethical 'training'.

As discussed above, Bennett-Levy argues that research leads to the conclusion that above all else, therapy trainers should be looking for ways to encourage and develop reflective ability in their students. ${ }^{92}$ By highlighting this fact I have sought to bring to the fore the formative and educational significance that deliberate reflection on one's philosophical practice may have from the perspective of the contemporary practice of philosophy as a way of life.

As discussed above, recent years have seen a surge in books, articles and projects designed to encourage a return to philosophical ways of living. Underpinning and uniting many of these has been the belief that applying ideas of practical ethics can have a therapeutic, resiliencebuilding or otherwise helpful effect. The conclusions of the reading of ethical training that I have offered here lead inevitably to the idea that any such initiatives, in order to impart the greatest value possible, should seek to promote and develop reflection; both on the key philosophical ideas introduced and the individual's attempts to live by them.

Efforts to embed this component into modern teaching of philosophy as a way of life may look to research in education as well as the developing body of literature in the field of therapist training. In recent years for example, CBT-based training programmes have sought to capitalise on the value of reflection through the introduction of Self-Practice/SelfReflection (SP/SR) activities. ${ }^{93}$ In SP/SR, therapists are required to practice therapeutic interventions on themselves and then to reflect on the experience in a structured fashion afterwards. A number of studies have demonstrated a range of positive effects from SP/SR

\footnotetext{
${ }^{92}$ Bennett-Levy 2006, p.61. Importantly, he argues that such research also demonstrates that reflective ability can be improved through practice.

${ }^{93}$ Bennett-Levy, 2001
} 
including improved self-perceived competence, ${ }^{94}$ deeper understanding of therapy rationale, enhanced self-knowledge ${ }^{95}$ and increased confidence with working with complex patients. ${ }^{96}$ Early evidence to suggest that advanced reflective ability is itself associated with improved clinical performance has also begun to be uncovered. ${ }^{97}$ Building on such research, BennettLevy and colleagues describe a 5-stage process used to encourage trainee therapists when reflecting on their experience following the self-practice of therapy techniques:

1. Observe the experience (e.g. how did I feel at the time, and what did I notice?)

2. Clarify the experience (e.g. was it helpful? What was happening?)

3. Implications of the experience for my client practice?

4. Implications for how I see myself? Both personally and as a therapist?

5. Implications for my understanding of cognitive therapy and theory?

By providing structure in this way and giving reflective prompts, trainees can be supported to engage in deeper and more constructive reflection. ${ }^{98}$

So what can contemporary teachers and authors of practical philosophy take from such work and how can the value of such reflection be used to support the extent to which people engage with and benefit from practising the ideas of ancient practical ethics?

Practising the techniques of Stoic or Epicurean thought is a central feature of many of the popular books of practical philosophy that have appeared in recent years. Research findings

\footnotetext{
${ }^{94}$ Davies et al. 2014

${ }^{95}$ Bennett-Levy et al., 2001

96 Thwaites et al., 2015

${ }^{97}$ Chellngsworth \& Farrand, 2013

${ }^{98}$ Bennett-Levy et al., 2009. It is noteworthy that the use of reflective prompts and structured reflection is a mainstay of much training and education in modern healthcare (e.g. Johns, 1995)
} 
suggest that extending this to encourage something akin to Bennett-Levy's SP/SR would support deeper understanding of the philosophical techniques and increased benefit from their use. ${ }^{99}$ In practise, this would mean encouraging not only the self-practise of philosophical techniques and ideas, but deliberate and structured reflection on such practise afterwards. The reader newly introduced to the Epicurean division of desires for example ${ }^{100}$ may be encouraged to practise forgoing the satisfaction of unnatural desires over a period of several days. After which they may be encouraged to follow a process of structured reflection on the experience. One could, for example, do so by adapting the process described above and utilised by Bennett-Levy and colleagues in the context of therapist training:

1. Observe the experience (e.g. how did I feel at the time, and what did I notice?)

2. Clarify the experience (e.g. was it helpful? What did I find easy or difficult about it?)

3. What might be the implications of this experience for how I may live my life?

4. What are the implications for my understanding of Epicurean theory?

\subsection{SP/SR for philosophy as a way of life}

As mentioned above, self-practise of philosophical ideas has featured in several of the contemporary publications mentioned in this article ${ }^{101}$ and something resembling the SP/SRstyle activities I have described here have featured in the programme of Stoic Week. ${ }^{102}$ Similarly, prominent authors in the field such as Donald Robertson have developed materials

\footnotetext{
${ }^{99}$ Interestingly, research has reliably shown that self-referenced material is better recalled than other types of information. (Hartlep \& Forsyth, 2000)

${ }^{100}$ Letter to Menoeceus, 127

101 e.g. Robertson (2012); Pigliucci (2017).

${ }^{102}$ See the Stoic Week Handbook (Gill et al., 2016) for example.
} 
such as the Stoic Self-Monitoring Form to help students and readers in the self-practice of philosophical techniques. But in none of these has the formative value of reflection been emphasised or sufficiently harnessed. The reading I have offered here suggests that teachers and authors should seek to support students and readers in going beyond the mere selfpractice of such techniques. Deliberate reflection on the experience and on the associated ideas should be encouraged and this intention should be central in the minds of those describing and introducing these ideas.

In describing SP/SR style activities for practical philosophy I am both drawing attention to the way in which such activity featured in the ethical training of a range of ancient thinkers, and also considering how this can be used fruitfully in contemporary practice. A body of modern psychological research gives indications as to how to make such reflective activities as useful as possible. SP/SR activities have been found to encourage deeper and more constructive reflection for example when students are required to post their reflections on a shared blog space and to comment on each other's' reflections. ${ }^{103}$ In part, the reasons for this seem to be that a public and interactive reflective process encourages the sharing of ideas and a more complete engagement with the process. That reflection can be especially productive when carried out in social environments has also been supported by the work of social psychologists such as Ursula Staudinger, who have shown that people provide 'wiser' answers to everyday problems when having reflected on the issues with another than when having done so alone. ${ }^{104}$ Consequently, teachers and authors seeking to harness the value of reflection should look for ways of encouraging and supporting interaction between learners

\footnotetext{
${ }^{103}$ Farrand, Perry \& Linsley, 2010

${ }^{104}$ Staudinger, 1996
} 
during the reflective process. In projects such as Stoic Week - a project running on set days, geared largely towards taking a practical and therapeutic value from the practise of Stoic exercises, and carried out primarily online - the opportunity to build on such activities is clear. The provision and use of online blog spaces onto which participants post their reflections of having carried out Stoic exercises should be a central feature of each days' practice. ${ }^{105}$ Research suggests that having staff involved in the programme read and respond to some of these reflections, as well as encouraging peer supervision through commenting on each other's posts is another important way of making such exercises as constructive as possible. $^{106}$

Clearly, such activities are less ideally suited to books, which may be picked up and read by many different people at different times. Despite this, providing readers with practical exercises and reflective prompts to consider afterwards should remain central to books seeking to impart some of the formative and character developing aspects of ancient practical ethics. Importantly, the significance of such activities - both for better understanding and retaining the philosophical theory itself ${ }^{107}$ and also in terms of enhancing the practical benefit they may take from engaging in such ideas - should be made clear to readers.

In this regard, authors may be advised to seek to adopt an approach centred around the concept - so important in both therapeutic approaches such as CBT and the philosophical approach advocated by the likes of Socrates and Epictetus - of 'guided discovery' or Socratic questioning. Guided discovery is a concept central to evidenced-based psychotherapeutic

\footnotetext{
${ }^{105}$ Whilst such online spaces have been utilised by Stoic Week previously, I suggest that more should be made of this to make clear to participants the value of engaging with such interactive and reflective components of the programme.

${ }^{106}$ Farrand, Perry \& Linsley, 2010

${ }^{107}$ Hartlep \& Forsyth, 2000
} 
approaches such as low-intensity CBT. In it, readers and clients are supported through the use of therapeutic materials with examples and questions which enable them to better understand key ideas and how they relate to their own situation and symptoms. To bring this into the world of applied philosophy, authors ought to consider how everyday examples of people using techniques could be woven into their works. ${ }^{108}$ Similarly, the use of Socratic questions and reflective prompts which encourage the reader to reflect on how the self-practise of techniques impacted them, will likely be of significant value. ${ }^{109}$

\section{Conclusion}

Many of the insightful, accessible and practical books that have appeared in recent years ${ }^{110}$ have made significant contributions to introducing a wider public to the value of a philosophical approach to everyday life. However, variable space in such works has been dedicated to actively promoting readers' reflective capacity or encouraging them to reflect on the ideas they are being introduced to. Following the implications of the reading that $I$ have developed here, it appears that as well as introducing readers to philosophical ideas in engaging and accessible ways, authors and teachers in this field should also have this aim in

\footnotetext{
${ }^{108}$ Massimo Pigliucci's How to be a Stoic (2017) is notable for containing many good examples of how he has related ideas from Stoic philosophy to his own life, using day to day examples such as how he responded to having a wallet stolen. (see for e.g. pages 173-4)

109 To the reader introduced to the idea found in Marcus Aurelius' Meditations for example that one's purple robe is merely sheep's wool dyed in fish blood (6.13), prompts and questions that encouraged a similar consideration of the objects occupying the desires of readers could be used. e.g. 'What did you notice when you looked at the objects around you or the objects of your everyday desires? How did you see these things in this new light? How, if at all, did this change your relationship to them?' etc.

${ }^{110}$ E.g. Pigliucci (2017), Irvine (2009), Robertson (2013) and Evans (2012).
} 
mind. Future research in this area would be useful to examine the effect that promoting reflection can have on the extent to which students engage with and benefit from philosophical ideas.

Himself convinced that philosophy could shape and inform our lives in useful and productive ways, Epictetus remarked that 'philosophers recommend that we shouldn't be contented merely to learn, but should add practise too and then training'. ${ }^{111}$ As ideas regarding the usefulness of philosophy as a way of life begin to flourish again, and in light of the reading offered here, we might be inclined to add that in fact philosophers should not be contented merely to learn, practice and train, but should add reflection too.

${ }^{111}$ Epictetus Discourses 2.9.13 


\section{$\underline{\text { References }}$}

Alberts, G. \& Edelstein, B. (1990) 'Therapist training: a critical review of skill training studies' Clinical Psychology Review, 10, pp. 497-511

Aubry, G. (2013) 'La philosophie comme manière de vivre et l'antiphilosophie' in Davidson, A. \& Worms, F. (eds) Pierre Hadot L'enseignement des antiques l'enseignement des modernes Paris : Presses de l'Ecole normale supérieure $2^{\mathrm{e}}$ édition

Aurelius, M. (2006) (trans.) Hammond, M. Meditations Penguin Classics: London

Beck, A. T. (1976) Cognitive Therapy and the emotional disorders International Universities Press: New York

Bennett-Levy, J., Turner, F., Beaty, T., Smith, M., Paterson, B. and Farmer, S. (2001). The value of self-practice of cognitive therapy techniques and self-reflection in the training of cognitive therapists. Behavioural and Cognitive Psychotherapy, 29, 203-220

Bennett-Levy, J. (2003) 'Reflection: a blind spot in psychology?' Clinical Psychology July, pp.16-19.

Bennett-Levy, J. (2006) 'Therapist Skills: A Cognitive Account of Their Acquisition and Refinement' Behavioural and Cognitive Psychotherapy (34) pp.57-78

Bennett-Levy, J., \& Thwaites, R. (2007) 'Self and self-reflection in the therapeutic relationship: A conceptual map and practical strategies for the training, supervision and 
self-supervision of interpersonal skills'. In Gilbert, P. \& Leahy, R., L. (Eds.), The therapeutic relationship in the cognitive behavioral psychotherapies (pp. 255-281). New York: Routledge/Taylor \& Francis Group.

Bennett-Levy, J., Thwaites, R., Chaddock, A., \& Davis, M., (2009) 'Reflective Practice in in Cognitive Behavioural Therapy: The engine of lifelong learning in Reflective Practise' in Psychotherapy and Counselling (eds) Dallos, R., \& Stedmon, J. Open University Press Berkshire

Bergsma, A., Poot, G., \& Liefbroer, A. (2008) 'Happiness In The Garden Of Epicurus’ in Journal of Happiness Studies (9) pp.397-423

Binder, J. L. (1993). 'Is it time to improve psychotherapy training?' Clinical Psychology Review, (13) pp.301-318.

Binder, J. L. (1999). 'Issues in teaching and learning time-limited psychodynamic psychotherapy' Clinical Psychology Review, (19) pp.705-719.

Bolton. G, (2001) Reflective Practice Paul Chapman Publishing: London

Boud, D. \& Walker, D. (1998) 'Promoting reflection in professional courses: the challenge of context' Studies in Higher Education (23) pp.191-206.

Boud, D., Keogh, R., Walker, D. (1985a) Reflection: Turning experience into learning Abingdon: Routledge 
Boud, D., Keogh, R., Walker, D. (1985b) 'Promoting Reflection in Learning: A Model' in Reflection: Turning experience into learning Abingdon: Routledge

Chellingsworth, M., \& Farrand, P. (2013). 'Is reflective ability a predictor of clinical competency?' Paper presented at the BABCP Annual Conference, June. London. United Kingdom.

Cooper, J. (2012) Pursuits of Wisdom: Six ways of life in ancient philosophy from Socrates to Plotinus Princeton University Press: Oxfordshire

Davis, M. Thwaites, R., Freeston, M., Bennett-Levy, J. (2014) 'A Measurable Impact of a Self-Practice/Self-Reflection Programme on the Therapeutic Skills of Experienced Cognitive-Behavioural Therapists' in Clinical Psychology and Psychotherapy

Del Nido, D. (2018) 'Pierre Hadot on Habit, Reason and Spiritual Exercises' Journal of Religious Ethics (46.1) pp.7-36

Epictetus (2014) (trans) Hard, R. (ed) Gill, C. Discourses, Fragments, Handbook Oxford University Press: Oxford

Erler, M., \& Schofield, M. (1999) 'Epicurean Ethics' in The Cambridge History of Hellenistic Philosophy Cambridge University Press: Cambridge 
Evans, J. (2012) Philosophy for Life and Other Dangerous Situations Random House: London

Farrand, P., Perry, J., \& Linsley, S. (2010) 'Enhancing Self-Practice/Self-Reflection (SP/SR) Approach to Cognitive Behaviour Therapy Training Through The Use Of Reflective Blogs' Behavioural and Cognitive Psychotherapy pp.1-5

Gill, C. (2014) 'Introduction’ in Discourses, Fragments, Handbook Oxford University Press: Oxford

Gill, C. (2007) 'Marcus Aurelius' in Bulletin of the Institute of Classical Studies No. 94 pp. $175-187$

Gill, C. (1985) 'Ancient Psychotherapy’ in Journal of the History of Ideas Vol. 46 No. 3 pp.307-325

Gill, C., Ussher, P., Sellars, J., Lebon, T., Evans, J., Garratt, G., \& Robertson, D. (2016) ‘Stoic Week Handbook 2016’ accessed online: https://modernstoicism.com/wpcontent/uploads/2016/10/Stoic-Week-2016-Handbook-Stoicism-Today.pdf

Hadot, P. (1995) (trans) Chase, M. Philosophy As A Way of Life Blackwell Publishing: Oxford

Hadot, P. (2009) (trans) Djaballah, M. The Present Alone Is Our Happiness Stanford University Press: Stanford 
Harrison, P., \& Fopma-Loy, J.L., (2010) 'Reflective Journal Prompts: A Vehicle for Stimulating Emotional Competence' in Nursing Journal of Nursing Education Vol. 49, No. 11

Hartlep, K, L. \& Forsyth, G., A. (2000) 'The effect of self-reference on learning and retention' Teaching of Psychology Vol. 27 pp.269-271

Irvine, W. (2009) A Guide To The Good Life: the ancient art of Stoic joy Oxford University Press: Oxford

Johns, C. (1995) 'Framing learning through reflection within Carper's fundamental ways of knowing in nursing' Journal of Advanced Nursing. Vol 22 pp.226-34

Laertius, D. (2005) (trans) Hicks, R. D. Lives of The Eminent Philosophers Books I-V Loeb Classical Library Harvard University Press: Cambridge

Laertius, D. (2005) (trans) Hicks, R. D. Lives of The Eminent Philosophers Books VI-X Loeb Classical Library Harvard University Press: Cambridge

LeBon, T., (2018) ‘Stoic Week 2018 Report Part 3: Impact on Wellbeing' available at: https://modernstoicism.com/wp-content/uploads/2018/12/Stoic-Week-Report-Part-32018-.pdf

Long, A., A. (1974) Hellenistic Philosophy Gerald Duckworth \& Company Limited: Bristol 
Long, A., A. (2002) Epictetus: A Stoic and Socratic guide to life Oxford University Press: Oxford

Mahoney, M. J. (2000). 'Training future psychotherapists'. In Snyder, C., R. \& Ingram, R., E. (eds.) Handbook of Psychological Change (pp. 727-735). New York: Wiley.

Narcy, M (2000) 'Exercices spirituels' et philosophie antique : la zéro degré du sujet’ Rue Descartes No.27 pp.59-65

Nehamas, A. (2000) The Art of Living: Socratic Reflections from Plato to Foucault University of California Press: London

Nussbaum, M. (1994) The Therapy of Desire: theory and practice in Hellenistic Ethics Princeton University Press: Oxfordshire

Padesky, C. (1993) 'Socratic Questioning: Changing Minds or Guiding Discovery?' Keynote address delivered at the European Congress of Behavioural and Cognitive Therapies London, September $24^{\text {th }} 1993$

Pigliucci, M. (2017) How To Be A Stoic Ebury Publishing: London

Plato (2003) 'Apology’ in The Last Days of Scorates Penguin: London 
Raydams-Schils, G. (2010) 'Philosophy and Education in Stoicism of the Roman Imperial Era' Oxford Review of Education Vol.36 No. 5 pp.561-574

Robertson, D. (2010) The Philosophy of Cognitive Behavioural Therapy (CBT): Stoic philosophy as rational and cognitive psychotherapy Karna Books Ltd: London

Robertson, D. (2013) Stoicism and The Art Of Happiness Hodder \& Stoughton: Croyden

Robertson, D. (2012) Build Your Resilience Hodder Education: London

Schön, D. (1983) The Reflective Practitioner Ashgate Publishing House: Aldershot

Sellars, J. (2009) The Art Of Living: The Stoics on the nature and function of philosophy $2^{\text {nd }}$ Edition Ashgate Publishing: London

Sellars, J. (2007) 'Stoic Practical philosophy in the imperial period' in Bulletin of the Institute of Classical Studies Supplement (94) pp.115-140

Sellars, J. (2017) 'What is philosophy as a way of life?' in Parrhesia Vol. 28 pp.40-56

Seneca (2015) (trans) Graver, M. \& Long, A., A. (eds) Asmis, E., Bartsch, S., \& Nussbaum, M., C. Letters on Ethics to Lucilius University of Chicago Press: Chicago

Seneca (2008) (trans) Davie, J. Dialogues and Essays Oxford University Press: Oxford 
Sharpe, M. (2014) 'It's not the Chrysippus You Read: On Cooper, Hadot, Epictetus and Stoicism as a Way of Life' Philosophy Today

Sharpe, M. (2016) 'What Place Discourse What place discourse, what role rigorous argumentation? Against the standard image of Hadot's conception of ancient philosophy as a way of life' Pli pp.25-54

Skovholt, T., Ronnestad, M., \& Jennings, L. (1997) 'Searching for Expertise in Counselling, Psychotherapy and Professional Psychology' in Education Psychology Review Vol. 9 No. 4

Skovholt T., M. (2001) The Resilient Practitioner: burnout prevention and self-care strategies for counselors, therapists, teachers, and health professionals. Boston: Allyn and Bacon.

Staudinger, U. (1999) (eds) Hess, T., M. \& Blanchard-Fields, F. 'Social cognition and a psychological approach to an art of life' in Social Cognition and Aging Academic Press: New York

Staudinger, U. (1996) (eds) Baltes, P. \& Staudinger, U. 'Wisdom and the social-interactive foundation of the mind' in Interactive Minds: life-span perspectives on the social foundation of cognition Cambridge University Press: USA

Sorabji, R. (1997) 'Is Stoic Philosophy Helpful as Psychotherapy?' Bulletin of the Institute of Classical Studies Supplement No. 68 pp.197-209 
Thwaites, R., Cairns, L., Bennett-Levy, J., Johnston, L., Lowrie, R., Robinson, A., Turner, M., Haarhoff, B., Perry, H. (2015) 'Developing Metacompetence in Low Intensity Cognitive-Behavioural Therapy (CBT) Interventions: Evaluating a Self-Practice/SelfReflection Programme for Experienced Low Intensity CBT Practitioners' in Australian Psychologist (50) pp.311-321

Williams, B. (1994) 'Do Not Disturb’ London Review of Books Vol 16. No. 20 pp.25-26 